\title{
Building up European Identity: From the Chimney Smoke ${ }^{1}$
}

\author{
Dragan Popadić ${ }^{2}$ \\ Faculty of Philosophy, Belgrade
}

The fact that the first Yugoslavia and its successors originated in the periods of severe ethnic conflicts and proved to be short-lived entities contributed to high salience of ethnic identity and strength of ethnic nationalism as well as endemic weakness of civic identity of their citizens. The three attempts in these countries at building an identity that would serve to balance ethnic identity and prevent ethnic conflicts are briefly described in the paper: promoting "Yugoslavism“ in the SFRY, developing civic identities in its successors, and promoting European identity in nowadays Serbia. One of the great obstacles for such aim stems from the linguistic confusion that has persisted for a long time in public, political and scientific discourse. The meaning of "Yugoslavism" ranged from attachment to joint country to supra-ethnic identity. There is no single word in the Serbian language which designates national not ethnic - identity of its citizens. As for Europe, the phrase "European identity" is used in a deliberately unclear way (as a geographical settlement, sharing specific values, membership in political community, etc.), increasing the confusion in the public discourse. Recently, great hopes have been placed in fostering positive attitudes towards European integration and developing the so-called European identity. What is lacking for this process to be more efficient is moving away from primordialistic conceptions of identity, a relatively stable and well-formed national identity, and the consensus among political elite regarding the necessity of such a path. In current conditions, the pro-European campaign is conducted through evasive messages but, being like this (and, perhaps, in current conditions precisely because of that), it has a greater chance to succeed than the previous two attempts, whose future should have been brighter.

Key words: ethnic identity, national identity, European identity, Yugoslavism, European integrations.

1 This is the enlarged version of the paper presented at MIRICO final conference, at Goethe-Universität, Frankfurt am Main, October 24-24, 2008. This paper is partly the result of the work on the project "Psychological problems in the context of social changes", funded by the Ministry of Science and Technological Development of Serbia (No. 149018D). 
I built on the sand
And it crushed.
I built on the rock
And it crushed
This time
I'll start building
From the chimney smoke.

(Leopold Staff: Foundations)

Both Yugoslavias - the Kingdom of Yugoslavia, established after the First World War ${ }^{3}$, and the one formed at the end of the Second World War - joined nations that had just ended mutual bloody fights. The remarkable enterprise had its cost: the social body was from the very beginning endangered by the virus of ethnic nationalism. Ethnic nationalism was constantly seen as the greatest menace for national security, persecuted and sanctioned. When, in official ideology and public opinion, the idea prevailed that it was extinct or so weak that it was practically harmless, ethnic nationalism was set free and did exactly what was suggested by the warnings all the time - destroyed the organism where it dwelt.

In this paper I will briefly describe three attempts at building an identity that would serve to balance ethnic identity and subsequently prevent the risk of ethnic conflicts. One such attempt was promoting "Yugoslavism“ in the Socialist Federal Republic of Yugoslavia (SFRY); the second refers to developing civic identities in ex-Yugoslav countries, and the third is the attempt of promoting European identity. Although the third attempt encounters greatest ambiguities, it has a better chance to succeed than the previous two, whose future should have been much brighter (hence the relation with the poem taken as a motto of the paper).

\section{Horror accurationis}

In the Serbian language, the same word ("nacija") and its derivatives are used to designate concepts that refer not only to ethnic community but to civic community as well. The same applies to the word "narod". „Nacionalnost" (nationality) can also mean either citizenship or ethnic membership. Both usages are equally common: in the Serbian translations of „United Nations“, "League of Nations“, „National Bank“ or "National television“, the words "nacija/nacionalna" and „narod/narodna“ appear referring to the state(s), but the same words are used to refer to different ethnic groups within the state. Similarly, „nationality“ in official forms and documents such as

3 The Kingdom was formed in 1918 under the official name „The Kingdom of Serbs, Croats and Slovenes", although the term Yugoslavia was used as a colloquial name from the very beginning. The country changed the name to „Kingdom of Yugoslavia“ in 1929. 
passports should be understood as "citizenship", but in other contexts it means belonging to an ethnic group and can be translated as "narodnost", "nacionalna pripadnost" or „etnička pripadnost“. To make things more confusing, the words „nacija" and "narod" are not synonymous; instead, political discourse insists on differentiating between the terms „nacija“, "narod"4 and „narodnost" - they allegedly refer to different developmental levels of ethnic groups in their progression from tribe to nation. „National identity" (translated into Serbian) can refer to the quasi-primordial sense of shared descent and distinct cultural tradition, but it can also mean - to apply Tajfel's (1978) definition of social identity - that part of individuals' self-conception which derives from the knowledge of their membership in the state, together with the value and emotional significance attached to that membership. In that sense, it is less precise to speak about a „Western“ and "Eastern" model of the nation as Smith did (Smith, 1992)5: the word "nacija“ (nation) simply has multiple meanings.

It is well known that even in academic discourse the terms "nation“, „ethnicity" and their derivatives are often blurred and that they change their meanings even in the works of the same authors. The review of the usage of these concepts in domestic and foreign literature can be found elsewhere (Milošević-Đorđević, 2003). Poutignat and Streigg-Fenart (Putinja \& StrefFenar, 1955/1997), as many others, warn that such ambiguity is inevitable in this field. First, whichever criterion (culture, language, religion, common ancestry...) or their combination we use to define these concepts, it will turn out that they are unclear at least as much as the terms that are to be defined. But besides this, the authors emphasize something especially relevant for our topic: not only that this lack of conceptual distinctiveness and contextual sensitivity poses no obstacle for their usage - on the contrary, they contribute to their usability and usefulness in communicative practice.

The lack of words should not be blamed on the language or dictionaries; such a situation is the result of an unwillingness to clearly distinguish between the two concepts, irrespective of which terms would be used. Confusion of these terms, however, leads to the confusion of concepts; it is extremely difficult to think about concepts that cannot be named easily. Bearing in mind the extreme simplicity of these truths, if vagueness in the political discourse about nation and ethnicity has persisted for so long, and is much greater than necessary, its consequences must be planned or welcome. In the paper, we will come across new examples of this rule that deserves to

4 In spite of the fact that the word "narod" is a calque of the Latin word nation.

5 As Smith (1992:61) puts it, the "Western“ model emphasizes the centrality of a national territory, a common system of homeland, a common system of laws and institutions, the legal equality of citizens in the political community, while the „Eastern“ model emphasizes ethnic descent, language, customs, religions and rituals etc. 
be explicitly formulated as (to adapt the Latin saying that Natura abhorret a vacuo) „Politics abhors clarity“.

Although ethnicity was seen from a predominantly primordialist perspective in Yugoslavia, as a kind of belonging to an extended family with fixed characteristics of the individual and the group, the Yugoslav case can be one of the best illustrations for the opposite, constructionist approach. Specific socio-cultural and political contexts were the factors that created social identities and played decisive roles in their waxing and waning, their labelling and apparent self-evidence. ${ }^{6}$ Nations were constructed through the political process, their characteristics were the results of negotiation, and nationalist leaders were and still are struggling to find and establish stable identity markers that can differentiate groups with almost the same language, customs and history. Political elites used this constructed ethnicity as a tool to satisfy their own interests, systematically emphasizing ethnic identity and provoking ethnic conflicts. On the other hand, national identity, defined as civic identity, loyalty to the community of laws and institutions, seeing oneself as a member of the state with legal-political equality, has failed to win adequate attention and theorization. The endemic weakness of such national identity, which can be recognized in language and is partially caused by language, poses an important obstacle to the democratization and integration of Serbian society into the international community.

\section{Identities and their markers}

It is well known how easily social categorization, the very division into Us and Them, can lead to inter-group tensions and discrimination. This is one of the most important premises of the influential Social identity theory (Tajfel, 1978) and Self-categorization theory (Turner et al, 1987). As soon as we categorize people into Us and Them, we start to make biased comparisons and behave more cooperatively, empathetically towards Us and to depreciate and disparage Them. Experiments have shown that the reason for categorization and consequent discrimination can be formed on almost any basis, no

6 Muslims (with a capital M) were recognized as nationality in SFRY in 1971. In the meantime, the term „muslim“(with a small $\mathrm{m}$ ) is used only in the meaning of religious affiliation, for adherents of Islamic religion. Such usage allows (or: demands) rather strange identifications as „Muslim who is not a muslim“, or „muslim who is not a Muslim“. After the independence of Bosnia and Herzegovina, the majority of Muslims accepted the new name - „Bošnjak“ (Bosniak). The 2002 Census in Serbia and 2003 Census in Montenegro allowed both ethnic self-identifications - Muslims and Bosniaks.

Until the late 19th century the term "Macedonians“ designated regional description but not ethnicity. Language, as an important identity marker, followed the destiny of political divisions. With the dissolution of SFRY, the Serbo-Croatian language, as one of the official languages in SFRY, also ceased to exist, and gave rise, through specific linguistic engineering, to four new languages: Serbian, Croatian, Bosnian and Montenegrin. 
matter how trivial: even random assignation managed to provoke in-group favouritism in laboratory experiments! A single identifier, that for any reason creates a distinction between two groups, starts to produce specific dynamics within the groups and between them. There are as many social identities as there are groups we belong to, but - as Self-categorization theory proposes it depends on the specific social context which levels of self-categorizations will be more or less salient.

Of course, a social identity will be more formed and more salient (and subsequently play a more important role) if it is the product of deliberate and systematic activities, called the politics of identity. In more detail, the politics of identity is an attempt to choose, elaborate and transform identity markers into a system of inter-connected values and symbols that enable one group to transform, discern and oppose other groups (Stojković, 1993). Nationalities possess a lot of identity markers whose aim is to make national identity salient, important, stable and affectively saturated. Nations have their names, territories on maps, their anthems, flags and coats of arms, and many more other mutually related symbols.

\section{Changing saliencies}

The multitude of social identities are inter-related and hierarchically structured within the Self. They differ, inter alia, in their saliency - i.e. the probability of being invoked by self or others, in their psychological centrality, in their personal and cultural evaluation.

The building of national identity and its place in identity salience hierarchy is almost never allowed to be completely spontaneous. It is a part of elaborate identity politics where the identities are intended to serve many societal goals. At other times, it becomes functional to change the primacy of social identities - to strengthen one and moderate the other. This process is also part of the politics of identity and has at its disposal various strategies formulated in social theory.

The strategy of de-categorization - inviting people to avoid thinking about each other in terms of problematic category membership and to focus on other categories or individual characteristics - proved to be unstable and difficult to sustain, especially if the problematic social identity is vivid, cannot be easily proclaimed as illusory, trivial or bad, or still plays an important role. In that case, a better approach is to reduce the salience of existing social categories by introducing new ones (Hewstone, 1996). Like the lesson from the alleged Indian story that in each of us lives a good and an evil wolf and the better fed prevails, one strategy for fighting against ethnic nationalism was seen in the weakening of ethnic identity by making other identity(ies) more salient. 
One way of weakening a particular identity is crosscutting social categorization. In the group where one category (and boundaries produced by it) is salient, the second categorization should be involved so that categories cut across each other. Crossed social categorization corresponds to what Coser (1956) named „flexible social structure“ (p. 153), where „multiple conflicts crisscross each other and thereby prevent basic cleavages along one axis" (p. 153). According to him, multiple group affiliations are a balancing mechanism within the group structure. Stressing of class instead of ethnic affiliation in Yugoslavia during and after WWII can serve as a good example of useful cross-cutting that helped to pacify ethnic tensions; however, its usefulness was exhausted by the allegedly extremely successful class struggle that resulted in the disappearance of the exploiter class and the emergence of a classless society where ethnic divisions became salient again.

The second way of making one identity less salient is developing a superordinate, common in-group identity, that enables both groups, Us and Them, to use the more inclusive We. In that case, the goal is not to assimilate different categories by blurring and merging their identity in a single broader identity, but to involve a super-ordinate identity and distinctive subgroup identities (Hewstone, 1996). The new super-ordinate category will not only make the older one less salient and lessen prejudices, stereotypes and discrimination provoked by it, it will also lead to increased mutual pro-social behaviour and empathy by emphasizing group membership.

\section{Yugoslav identities}

In the Kingdom of Yugoslavia, the integrative element that was expected to neutralize the existing ethnic tensions was the idea of the Yugoslav nation conceived as an ethnic group (the South Slavs), with a common ancestry and common national character (Dvorniković, 1939). Such a concept is shown to have failed. In the Yugoslavia born after WWII, one of the central doctrines was that the new state should not be a "dungeon of nations", that all nations and ethnic groups should have - and actually do have - equal and maximal rights, and that thus attained "brotherhood and unity" must be taken care of „as the pupil of one's eye“.

One of the strategies for neutralizing ethnic nationalism and chauvinism consisted in promoting a Yugoslav identity. „Yugoslavism“ represented an attachment to the Yugoslav nation in the sense of the joint state, not at all the formation of a Yugoslav nation as an additional ethnic group. The feeling of loyalty to the Yugoslav community should have risen from the awareness of shared values and the building of socialist relations in the country, and not because of similarities in tradition and language. In the Yugoslav socialist society, as stressed by one of its leading ideologues Edvard Kardelj, „every worker can proudly call himself Yugoslav, a member of the Yugoslav socialist 
community, and by this he does not disavow his nationality nor his love towards his national language and culture" (Kardelj, 1996:267). In order to foster the sense of common belonging, closing in the frames of a republic (federal unit) should be discouraged. Cultural cooperation between the republics was stimulated, and (as a forerunner of the academic scheme and the Bologna process) the transition from one university to other was made easier, educational programs harmonized, joint textbooks published, and school excursions organized throughout the country (Marković, 2001:17). As a result, the feeling of belonging to the Yugoslav community, especially among the young, became stronger than the feeling of belonging to a particular nation ${ }^{7}$ and remained very important up to the end. ${ }^{8}$ A research conducted in 1971 (Rot \& Havelka, 1973) is illustrative for the situation and value orientations of the time. In that study, conducted on the sample of 790 secondaryschool students from Serbia, three kinds of relationships between (to use the modern scientific jargon) Yugoslav and ethnic identity were differentiated and measured. The authors labelled them as salient Yugoslav attachment when attachment to Yugoslavia is more important then attachment to one's own nation (ethnic group), divided Yugoslav attachment - giving equal importance to Yugoslav community and ethnic group, and limited Yugoslav attachment - giving priority to attachment to one's own national group. Only one-fifth of respondents showed decisive priority to ethnic over Yugoslav identity. Besides that, „limited Yugoslav attachment“ was positively correlated with ethnic distance, ethnocentrism and authoritarianism, as well as with religiosity and preference for autocracy vs. democracy, capitalism, and gender inequality.

Gradually, within the political elites of republics, the project of Yugoslavism was approached with caution and open resistance. It was perceived either as a concealed form of „etatism and bureaucratic centralism" or as a covert attempt at domination of the biggest nation. Even without attributing bad intentions, there was a fear among republican political elites, proven to be more nationalistic than the population, that the more popular Yugoslavism, the less attractive ethnic affiliations will be.

7 In a survey conducted in 1959 among more than 3,000 persons from the age of 18 to 25 throughout Yugoslavia, when asked „Do you feel primarily as Yugoslav or as Macedonian, Slovenian etc.?“, 68\% answered that they felt primarily as Yugoslavs (Marković, 2001:20).

8 A survey conducted in March 1989 on the sample of 4,990 young people from Yugoslavia revealed that $59 \%$ were ready to put the interests of Yugoslavia before the interests of other groups (class, national, generational, religious, political party, regional). 20\% claimed that they were ready to engage in the accomplishment of Yugoslav interests "much" and 54\% „very much“ (Vasović, 1990). In the same study, the most significant identification was with Yugoslavia: for 37\% of youth Yugoslav identity was „very important“, for 20\% „important“, for 11\% had „little“ importance and for 16\% „no importance“ (Baćević, 1990). The Yugoslav identification was above average in Montenegro, Bosnia and Herzegovina, Kosovo and Serbia proper. 
Some historians concluded that „alienation from the supra-national Yugoslav identity had started gradually and continuously among party leaders at least since 1964, maybe even since 1962 (Marković, 2001:52) and that since that moment Yugoslavia had been increasingly becoming a loose coalition of party oligarchies. Even so, the effect of promoting Yugoslavism on the number of citizens declaring themselves as Yugoslavs was still increasing for a long time and culminated not earlier than in the early 1980s. In the 1971 Census, 273,077 citizens or $1.33 \%$ of total population chose this identity. In the 1981 Census,, the number of Yugoslavs showed a dramatic rise: 1,216,463 or $5.4 \%$ of the population declared themselves as Yugoslavs (they were almost as numerous as Macedonians and more numerous than Montenegrins).

One's declaration to be of Yugoslav nationality has more weight than one's declaration that Yugoslav (national) identity is more important to him/her than ethnic identity. ${ }^{9}$ Civic and ethnic identities are not mutually exclusive as two civic or two ethnic identities are; they have originated from independent categorizations. In spite of this, in the Census questionnaire, two memberships appeared as concurrent within the same category, placed in the relation "either-or". To be put within the same categorization, „Yugoslavism“ first had to modify its meaning. This label was found to be especially convenient for people from ethnically mixed families. Gradually, Yugoslav nationality started to imply not only that somebody did not want to declare his/her ethnic affiliation or was unsure about it; the Yugoslavs started to call themselves "the seventh nation in the SFRY“. Formulated in reference to state and political community, it moved to the field of ethnic categorization, partly transformed to a form of supra-ethnicity and started to swallow particular ethnic identities. Such a course alarmed the guardians of ethno-nations. Divided over a number of issues, they were united in perceiving the danger and in their determination to confront it. The Yugoslav identity was an easy prey for nationalists because of its contested and ambiguous meaning, and the ambiguity was a consequence of the above-mentioned cultivated confusion between labels and concepts of national and ethnic identity.

In any case, the history of post-Tito's Yugoslavia is a history of the strengthening of ethnic regionalisms. As already said, for the nationally divided communist parties, ethnicity was a useful tool in their mutual struggle for

9 In some cases it is not clear in which of these two meanings somebody's declaring to be a Yugoslav should be understood. Josip Broz Tito also declared himself as Yugoslav several times, as did his war comrades and high party and state officials (see: Matvejević, 1982: 202). In 1971 Tito declared: „I say for myself: I am a Yugoslav and can’t be anything else. I am a Yugoslav by my obligations, by my position but also by my spirit. But I don't conceal that I was born in Croatia. Why should I stress now that I am a Croat? I grew up in Yugoslavia in the working class milieu. And hundreds of thousands are like this." Recently, Oliver Dulić, the Speaker of the Serbian Parliament until June 2008, declared his ethnicity as Yugoslav. 
economic and political power. The cases previously qualified as nationalism and chauvinism and sanctioned as such started to be interpreted as harmless or even progressive, and their actors viewed as victims of the communist regime's restriction of freedom and rights. The ghost of ethno-nationalism was released from the bottle, with the well-known outcome.

Yugoslav identity was built up on solid grounds, on a densely interwoven network of identity markers. At a symbolic level, it possessed plenty of wellrecognizable identity markers: from an anthem and flag to football dress and familiar contours of the border (but, nota bene: never had Yugoslav-wide elections or proper Yugoslav media). Yugoslavia was a globally respected country. Nevertheless, this identity could not survive and did not manage to save the Yugoslav community because its centripetal force was much weaker than the centrifugal forces produced in the Yugoslav republics. Its remnants can be recognized in many forms of the so-called "Yugo-nostalgia" among its former citizens around the world. In some cases, Yugo-nostalgia implies the wish to re-establish the Yugoslav state; much more often, however, it relates to the nostalgia for sharing a common cultural identity (Jansen, 2005).

\section{Yugoslavia without Yugoslavs}

The wars in the 1990s were waged under ethno-nationalist flags. The result was the dissolution of SFRY into several countries. One of them was the Federal Republic of Yugoslavia (FRY), formed on April 27, 1992. This country did not last very long: in February 2003 it was transformed into the State Union of Serbia and Montenegro. Although the official name of Yugoslavia was abolished by this act, it was unofficially retained and has its remnants even now (for example, the Internet domain .yu was valid until April 2010). This state union was also not long-lived: it split in May 2006, and Serbia and Montenegro became independent countries.

One of the important tasks in the newly established countries was to develop a new civic identity, to teach their citizens about the new country and to develop their patriotism - love and devotion to their new patria that replaced the old one. Additionally, the important job was to adapt the level of ethnic sentiments and ethnic identities to times of peace. Namely, ethnic mobilization, very useful during the wars, showed to be a burden for building good relations with neighbours and within the societies that remained ethnically mixed.

The first two entities (FRY and S\&M) were, according to criteria for countries, short-lived. For a long time they lacked the elementary identity markers: an anthem, a Constitution, a coat of arms, even the recognized frontiers. The third Yugoslavia was - as stated in one article title (Lendvai, 1991) intended to describe the second Yugoslavia but fitting even more 
with the next one - „Yugoslavia without Yugoslavs“. Even in statu nascendi these countries were perceived as temporary entities, not to mention that inter-republic relations and global processes indicated that the trend of defragmentation had not stopped. ${ }^{10}$ Ethnos was clearly predominant over demos but the dispute was about what ethnicities rested in the country. The majority in Serbia and a significant part in Montenegro insisted that "Montenegrins" should mean the citizens of Montenegro only, or a subgroup within Serbian ethnicity; a close majority in Montenegro argued that Montenegrins are a close but distinct ethnic group.

\section{Nameless identity}

Was the lack of identity markers of the newly born countries one of the causes of their weakness or a symptom of the conditions they were in? Both of these. On the one side, such a defect was a clear signal of how seriously that entity should be treated and how much was invested in it. It was a clear message that an interim political solution was at stake.

On the other side, such a situation actually complicated, in fact impeded, the formation of national identity, even if the political elite had seriously undertaken this. The problem is particularly grave if people who should develop affective ties and a common identity lack the most elementary identity marker - a common name. Naming the newborn country „Serbia and Montenegro" made the common name for its citizens not difficult, but impossible. During its short three-year existence, it had not even been suggested how its citizens can call themselves. And - let me make a pun - following the proverb Nomen est omen, out of Serbia and Montenegro emerged Serbia and Montenegro.

The current state, the Republic of Serbia, seems stable enough to conceive a stable loyalty of its citizens. Serbia has its name, anthem, flag and coat of arms, although with a disputed territory and population. And there is something else that is also disputed - the common name for its citizens.

As Balibar (2001) puts it, the persistency of name is a condition of every „identity“. What can be said, then, about the chance of developing an identity that does not even have a name! Let us take an example of two men living in Zrenjanin. They can without any difficulty find a word to say that they are the citizens of Zrenjanin ("Zrenjaninci"), or live in the same region ("Vojvođani"), or even in the same part of the region ("Banaćani") or to indicate their ethnic affiliation ("Srbin“, „Mađar“, „Slovak“), not to mention the easiness of labelling

10 Dejan Jović (2001) noticed an indicative detail. In October 2000, immediately after Slobodan Milošević resigned the Yugoslav presidency, the new Yugoslav president Vojislav Koštunica started his first address to the citizens saying „Good evening, Serbia!", not mentioning Yugoslavia at all. 
their professional or party membership. But there is no single word by which they can tell that they are the citizens of Serbia. There is no linguistic marker which would enable them to instantly and easily express their civic identity and recognize it as common. If someone tries that, one usually uses the word "Srbi" ("Serbs") and its derivatives, giving in that way an additional meaning to the word that refers to Serbs as an ethnic group. Because of that, the term embraces people who are ethnic Serbs but live in other countries. Also, it is quite awkward for some citizens of Serbia who belong to other ethnic origins to declare themselves as Serbs; on the other hand, many ethnic Serbs would treat this label as highly inappropriate for the „outsiders“ with different ethnic origin.

How to find a term which designates being a citizen of Serbia and which will help clarify the conceptual distinction between belonging to an ethnic group and belonging to a state? One possibility is to use the words "Srbijanac" and "Srbin" (Serbian and Serb). But the problem with this solution is that word „Srbijanac" is already assimilated and used as a localism for the inhabitants of central Serbia (i.e. Serbia proper and not Vojvodina), or for ethnic Serbs who live only in Serbia and not in other countries. It seems that the term originated in the $19^{\text {th }}$ century in Austria-Hungary with the aim to distinguish the ethnic Serbs who lived there from the ethnic Serbs who lived in the then Serbia.

One should not underestimate the role that the inability of easy and automatic expressing of identity has in its creation and preservation. Not only that the impossibility of symbolic representation hinders the formation of a concept and its use in communication. The lack of such markers in the symbolic repertoire of a community, even the absence of the word which can designate it, is a sign for the individual that it is something provisional. The absence of a word for belonging to the country impedes thinking, but also suggests that such country is probably a temporary community, not worthy of attachment and investment. In turn, such predictions will produce just these outcomes.

The problem of the absence of different words for ethnic belonging and civic membership exists in other ex-Yugoslav countries (languages) too. There are no different words for a citizen of Croatia and an ethnic Croat (maybe: „Hrvaćanin“ and „Hrvat"?), although one can make this distinction in English (Croatian vs. Croat). The same is true for Macedonia, Montenegro, and Slovenia. In Bosnia and Herzegovina, constituted of three ethnic groups, the word "Bosanac" (Bosnian) is intended for its citizens regardless of their ethnicity. It is symptomatic that some ethnic communities resist the use of this word, although it differs from the word which refers to ethnic affiliation ("Bošnjak", Bosniak), in fact, an archaism for the inhabitants of Bosnia.

The problem surely exists in many countries in the world too, but there are two important specificities regarding Serbia. First, in many of these countries, 
there is a word that serves to label civic membership, but this word also has another role - to assign ethnic identity as well. This word is burdened by two competing meanings that are both in use, maybe equally frequently. In short, there are two homonyms that have distinct meanings and make the distinction possible between two concepts (state and ethnicity). In the Serbian language there is no word whose meaning or one of the meanings refers to civic identity. Second, in these countries there is no such hyper-inflation of ethnicity as in Serbia, associated with heated clashes. Ethnic meaning of the word "Serb“ would completely overshadow other proposed usages and additionally is so emotionally loaded that other ethnic groups would resent to be thus identified. For example, if Albanians in Kosovo accepted to live in Serbia, this would mean that they would have to call themselves "We Serbs" or "We Serbians".

Linguistic vagueness and struggles around language characterized the situation in Kosovo and identity politics there. There is no word in Serbian for the inhabitants of Kosovo regardless of their ethnicity ${ }^{11}$ (while, for the inhabitants of the second autonomous region, Vojvodina, such a word exists). Again, this lack was of course not the cause of ethnic splitting but it was a strong message to both Serbs and Albanians there that they should not take this identity seriously. Long before the word "Šiptari“ became an insulting word for ethnic Albanians gladly used by Serb nationalists, the insistence to use this world instead of "Albanians" stemmed from the fact that it enabled to discern ethnic affiliation from citizenship of another country, Albania. ${ }^{12}$

\section{European identity}

The goal of the European project is not to form a European identity, but it is assumed that forming a European identity will make the European Union more attractive and stable for its members and, additionally, will attenuate national and ethnic identities of diverse groups whose past interaction abounds with hostilities and conflicts. In the case of Serbia, "European identity" is a new, popular topos in the public discourse, having predominantly positive connotations. It is used as a tool to motivate and mobilize citizens for the association with EU and/or foster „European values“. On the other hand, ethnic nationalists also use it to warn that EU has nothing to do with European identity and that the Serbs are entitled to it no matter what European bureaucrats think and do.

11 In English, „Kosovars“ refers to Kosovo citizens regardless of their ethnic affiliation. In Albanian, the word "Kosovarët" has the same meaning.

12 From the end of WWII to 1967 the official name for ethnic Albanians living in Yugoslavia was „Šiptari“ (resembling their self-designation „Shqiptarët"). The name „Albanians“ was reserved for the citizens of Albania, and the name „Arbanasi“ for their ethnic group. Such distinctions were not planned for other ethnic groups. Since 1967 the official name for former „Šiptari“ has become „Albanci“ (Albanians) (Imami, 2000). 
The possibility for politically opposed sides to use European identity in a positive context for different purposes (and to use it, if they want, with negative connotations as well) comes from the elusive meanings of both „European“ and „identity“, multiplied in the syntagm „European identity“.

If it was already possible in the early 70s to say, as reviewed in Brubaker \& Cooper (2000:3), that ,identity“ is a word „driven out of its wits by overuse" and the "purest of clichés", what can be said then for the situation in the 2000s? Introduced to denote something basic and abiding, it is used not only in everyday ,identity talk“, but in theoretical analysis in a very broad sense as well: to denote affiliation to political parties or subcultures, choice of lifestyle or involvement in social movements. Brubaker's and Cooper's analysis (Brubaker \& Cooper, 2000) convincingly shows how, in analytic and practical usage, identity ,tends to mean either too much or too little“. The use of strong concepts of „identity“ entails a series of deeply problematic assumptions related with its essentialist nature. The soft concept implies the more modern and popular assumptions that identity is constructed, negotiated, multiple, unstable, but such a concept is too weak for efficient theoretical work and differs from the ordinary meaning.

One probably expects that „Europe“ has a much clearer meaning than "identity", but this word is also overburdened by ambiguities in both public and political discourse related to European integrations. ${ }^{13}$ It is least used as a geographical concept, in which case belonging of Serbia to Europe is unproblematic but apparently of negligible importance. In political discourse, however, "Europe“ has this meaning rather often. As Kostovicova (2004) remarked, such geographic interpretations of Europe undermine the primacy of the EU, implying a lack of urgency, if not outright Euro-skepticism. If Europe should be understood simply as a continent, then it is obvious that Serbia is already in it, and that dealing with the issue of association to Europe and efforts to fulfil requirements for it are pointless, and that its entitlement should be universally recognized. ${ }^{14}$

„Europe“ is far more frequently an abbreviation for something not always clear. Sometimes Europe is an abbreviation for the European Union, and in that case it is also easy to see who belongs to such a Europe and who does not. Europe can be the collective name for European countries, i.e. countries

13 The similar (or, due to their higher metaphoricity, even greater) ambiguities exist in derivatives like „European path“, „Europeization“, „European family“ etc.

14 Vojislav Koštunica, during his presidency of the FR Yugoslavia, said: 'When I say Europe I mean Europe from the Atlantic to the Urals' (Fonet, October 8, 2002). Later on, during the election campaign in spring 2008, Koštunica, the then Prime Minister, whose party was opposed to the coalition „For a European Serbia“, commented in an interview: „The question of Europe is not so controversial, simply because we are here where we are, we are not beyond." (www.b92.net/info/emisije/utisak_nedelje.php?yyyy=2008\&mm=04\&nav_ id=294097) 
that are in the European continent, which is again a source of disputes, such as in the cases of Russia and Turkey.

The most important but also the most problematic and discussed meaning of "Europe“ is Europe as a specific cultural community, whose members have their own assumed cultural identity. This meaning is especially suitable for political (mis)use. First, it can be ascribed irrespective of formal membership to any political organization; pro-European forces cultivate it to make association to the EU more attractive; isolationist forces underline the European identity of Serbs to imply that it does not depend on EU decisions and is even opposed to EU values. ${ }^{15}$ But there are many difficulties with this meaning of "Europe“, not only in Serbia. Besides the fact that this meaning puts "Europeans" very close to a kind of supra-ethnic community, it is problematic how to define these characteristics in a way acceptable for those within and outside frontiers defined in such a way, and who "culturally and historically" more and less belong to such a Europe (Gvozden, 2007).

The same word - „Europeans" - has at least a threefold meaning: inhabitants of the European continent, citizens of the European Union, and people who share (unspecified) common European culture. The similar complication goes for „The United States of America“: its colloquial name ("America") has primarily a geographical meaning and its citizens are in many languages labelled by cognates of "Americans", but in that case there are no much instances of confusion (especially since Native Americans are "honoured" with the name „Indians"). In the case of Europeans, however, the fact that the same word serves to designate citizens of a supra-national community and the wider group is often either an obstacle or opportunity for intentional ambiguities.

\section{Europeans without Europe}

As it seems now, the European Union with its relatively short history and the population of more than 500 million is a prosperous creation with various possible directions of further development. Its citizens are divided in opinions as to what the main objective of „building the Europe“ is as well as what kind of entity the European Community should or is going to be

15 There is also a strong anti-European sentiment rooted in a part of the Serbian tradition closely tied to anti-modernism and anti-Semitism and recently promoted by the „New Serbian Right“. Its followers find the support for anti-European sentiments in, among others, teachings of the canonized Bishop Nikolaj Velimirović of the Serb Orthodox Church (1880-1956), who wrote: „All the modern European slogans were made up by Jews - the crucifiers of Christ: democracy, strikes, socialism, atheism, tolerance of all religions, pacifism, universal revolution, capitalism and communism... All this had been done with the intention to eliminate Christ... You should think about this, my Serb brethren, and correspondingly correct your thoughts, desires and acts." (see: Đorđević (Ed.), 2003). 
(e.g. Robyn, 2005). Citizens who are de iure European citizens largely differ in perceiving themselves as Europeans and in their attachment to EU. An investigation in 2007 showed that $49 \%$ of Europeans were „very attached“ or "fairly attached" to the European Union (Eurobarometer $68^{16}$ ) - a figure that may be read as too small or big enough.

In that research, the same question was posed to the respondents from several countries currently outside EU. It was shown that two-thirds of respondents in the Former Yugoslav Republic of Macedonia, 30\% of Croatians and $17 \%$ of Turks were attached to the European Union. In that case, „attachment to EU“ can be translated as a positive attitude towards it or a wish for integration of one's own country into EU. But is it possible to measure a sort of European identity in people who are not its citizens? There are a lot of such attempts in public opinion polls, e.g. in the polls conducted by the Serbian European Integration Office. ${ }^{17}$ When asked if they personally felt like a European, approximately $40 \%$ of Serbian citizens, in the period 2006-2009, responded with Yes, but what the respondents exactly regarded under feeling like a 'European' was left to their own (and our) imagination.

There are other, more systematic and scientifically grounded attempts but, as it were, with similarly dubious results. In an attempt to measure the European identity among citizens of Serbia and Montenegro (Franceško et al., 2005; Janičić et al., 2005), European identity was defined as „a subjective sense of belonging to Europe together with introjected beliefs, values, customs, and opinions which describe that group as a defined cultural and territorial community" (Franceško et al., 2005: 151). The scale intended to measure European identity consisted of five factors: exclusive national reference, globalization as a jeopardizing factor for small and poor nations, efforts for preserving national identity, confronting traditional values and technological civilization, and (with the lowest loading on the second-level factor) proEuropean orientation. The scoring implied that the greatest European identity was present in those with the greatest positive attitude towards EU and the most negative attitude towards one's own national group. Educational level showed the greatest correlation with pro-European orientation as well as, to a lesser extent, age and regional belonging.

This research illustrates well the obstacles in measuring identity among out-groups. In short, the scale consists of a minority of items that refer to the European Union and measure the attitude towards such an entity, and the remainder that concerns various value orientations that are not distinctively European values; the scale is said to measure the European identity although „openness towards the world" or "pro-European orientation" would be much more appropriate labels.

16 http://ec.europa.eu/public_opinion/archives/eb/eb68/eb68_en.htm

17 Data from www.seio.gov.rs. 
Generally speaking, if everything that correlates positively with the relation towards a particular group can be proclaimed as a component of the identity, there is a risk that for measuring particular group identity, it is not only unnecessary for the respondent to belong to this group, but his/her opinion about this group may be unnecessary as well.

Sometimes, information about the European identity of Serbian citizens is presented as something unproblematic that does not call for any clarification. In a recent report on a public poll conducted in February 2010, CeSID informs that the European identity of Serbian citizens is moderately developed, that three out of 10 people have a strong European identity and that intensity of the European identity equals 2.83 on the scale from 1 to $5 .{ }^{18}$

All in all, it seems that not only politicians but the scientists as well are capable of building up European identity out of nothing - belonging to EU is unnecessary, even the positive attitude towards Europe is unnecessary; for having European identity, it is enough to have specific attitudes towards globalization, technological civilization and one's own ethnic group.

Paradoxically, there is more sense in speaking of Yugoslavism when Yugoslavia no longer exists than of European identity among non-Europeans. If Yugoslavism is no longer conceived as exclusively civic identity but as a sort of the ethnic one, then the existence of Yugoslavia ceases to be a necessary condition for Yugoslavism anymore, regardless of whether it is conceived closer to primordialistic or constructivist/instrumental pole.

\section{„EU = SFRJ“}

The above subtitle quotes a graffito that Gvozden (2008) noticed and commented on in his article about Europe. He observes that its writers „see any kind of supranational political entity as the same evil as the former socialist Yugoslavia." (p. 11). But is this the only correct reading of this message? I will argue that apart from this legitimate interpretation, ambiguities of both the EU and SFRY allow a number of other possible meanings. Practically, it can be interpreted so that it is fully accepted by both adherents and opponents of association with the EU, but also in a way that at the same time allows other adherents and other opponents to completely reject it; simply - two Rorschach inkblots appear on both sides of the equation.

For citizens of ex-Yugoslav countries the most efficient way for explaining the potential integration in the EU is through a comparison of the EU with SFRY. Hence, the lack of such a didactic tool in public discourse can be rather surprising. I believe that this again reveals a preference for vagueness. A comparison of the $\mathrm{YU}$ and EU would demand what speaking about each 
of them separately does not: either the confirmation or the negation of the equation demands more explicit statements of what the both Rorschach inkblots represent for the speaker.

The European Union is undoubtedly identical with Yugoslavia in the sense that it is a political organization with supra-national legal system that involves a partial relinquishment of national sovereignties and thus affects what is the basis for national identity. Membership to the EU will correspond with membership to Yugoslavia in a sense that "Europeanism" does not exclude either membership to the states or membership to ethnic communities. Can identity based on such community be strong enough? The Yugoslav experience in fact gives a positive answer. Theories of social identity say the same emphasizing that one should not underestimate the power of identity born by the very act of forming a broader community. As the experiments in minimal group paradigm repeatedly show, classification into ad hoc groups according to unimportant and trivial criteria creates a group identity that results in individuals' favouring of their in-group. The formation of group identity and in-group favouritism are all the more stronger when the awareness of common interests and goals merges with the sheer in-group sentiment and is strengthened by identity markers such as, in the case of European Union, a common name, a common currency, flag, anthem, a "national day“, registration numbers, territory with clear frontiers and freedom of movement within it, common political institutions like Parliament and Council, etc. As it was underlined when speaking about Yugoslavism, the basis for such identity need not be anything coming from the past, but present values and goals and future accomplishments.

The idea of the European Union connected by a common cultural identity, Europe, understood as a cultural, spiritual and religious collectivity, resembles the concept of Yugoslavia as a community with common roots and tradition, something that in time became more and more similar to a supraethnic community. Such identity is something that can be recovered and strengthened, not built up.

Speaking in somewhat simplified terms, Europe-as-ethnic-group can fit easily in narratives in ethnic terms so habitual in Serbia, but it is a misleading concept. Europe-as-supra-nation is a much more accurate description. The inclusion in the organization of this kind would actually impede ethnonationalistic goals and sentiments - the danger which, according to Jovic (2009), nationalistic elite in SFRY were keenly aware of: „The realistic chance of Yugoslavia soon becoming a member of the EEC, in which case national identities would have found themselves under two supranational lids (Yugoslav and European), additionally augmented the sense of danger among the ethnic nationalists." (Jovic, 2009: 23). While discouraging ethnonationalistic feelings, membership to supra-national European community should at the 
same time strengthen the lack of civic identity in Serbia. As Jacobs \& Maier (1998) put it, „To be European means to be French or Belgian in the first place. Through the national identity, individuals can participate in the pool of European identity, but there is no other way to participate in it effectively. That means that nobody can become European without first acquiring a national identity (...). In other words, the new form of European citizenship and identity does not really transcend national identities, it is at the moment completely dependent on national identity." (p. 29).

But the important dilemma is the following: whether strong civic identity, so much needed in a newly born country, is a precondition for successful integration in the European community, or we can wait for an undeveloped civic identity to be strengthened once Serbia joined the community.

\section{Serbia-Europe relations}

The trends in the changing attitudes of Serbian citizens towards the European Union can be tracked down easily because it had been a frequent subject of opinion polls for several decades. Baćevićs review of survey results ${ }^{19}$ that covers the period from the 1980s to 2001 (Baćević, 2001) shows that at the end of the 1980s a clear majority of citizens expressed their acceptance of European integrations and experienced belonging to Europe as an important element of their personal identity. The erosion of acceptance and the rise of resistance and animosity started in the 1990s, and were formed primarily reactively, under the decisive influence of the perception of hostile attitudes of Europe and the world towards the "third“ Yugoslavia. Leading European countries recognized and supported the republics that exited the Yugoslav federation, which was interpreted by a majority in Serbia as an unjust and hostile act, responsible for the deepening of the crisis and for subsequent wars. Xenophobic attitudes were also induced by the powerful propaganda of the then regime that pictured Western European countries as aggressors. In that way, in 1992 only $12 \%$ of Serbs had confidence in the European Union; in 1993 the level of confidence sunk to $10 \%$.

This process resulted in a constant discrepancy between affective and rational (interest) reactions to the European Union. For example, in 1996 half of the citizens were for the entrance of Serbia in the European Union, but only $18 \%$ expressed their trust in it. Baćević emphasizes that the „rational determination for Europe and the European Union persisted during the decade of the worsening of the international position of the 'second' and 'third' Yugoslavia, survived isolation, sanctions, banning, bombing and all other forms of collective punishment of the Yugoslav and Serbian people by

19 The author refers to the results of investigations of the Centre for Political Studies and Public Opinion Research, Institute of Social Sciences. 
Western countries and the European Union“ (Baćević, 2001:51), but that this cognitive component of attitude was accompanied by a dissonant affective component - suspicion, hostility and resistance towards the EU and its institutions. Attitudes towards Western countries were contingent to their changing readiness to freeze or soften their relations with the Milosevic's regime.

In the post-Milosevic period after 2000 the situation remained the same: Serbian citizens mostly supported joining the EU but the distrust of European institutions persisted. They still wanted Serbia to be admitted to the EU much more than they clearly articulated positive attitudes towards or trust in the EU. Reviewing the data collected between 2000-2006 ${ }^{20}$, Bogosavljević (2007) concluded that a „referendum answer to the question about the accession of Serbia to the EU would be undoubtedly positive, but there exists a very significant amount of distrust in the EU, and a more serious lack of information what Serbia should do to be allowed to enter into the EU." (p. 52). The percentage of those who would surely vote for accession oscillated during that period around $60 \%$ while the percentage of those who were against association was around $9 \%$. About one fourth of citizens were afraid that there was a risk of the loss of cultural identity. Similar picture was found in later period. In the public polls conducted by the Serbian European Integration Office since 2002, the percentage of citizens who supported integration of Serbia with EU ranged over around one third (68\% in September 2002, 65\% in December 2009, with the peak of 72\% in December 2003 and the lowest point of $61 \%$ in December 2008). ${ }^{21}$

In addition to the above-mentioned research conducted on adult respondents, several studies dealt with the pro-European orientation of Serbian students. When asked how important for them was the social goal of fulfilling the conditions for the integration into the European Union, Serbian secondary school students expressed somewhat polarized opinions. While $28 \%$ of them rated this goal as exceptionally important, one fourth estimated it as of little or slight importance (Kuzmanović \& Petrović, 2009). The average importance of this goal was 3.44 on the scale from 1 to 5 . Somewhat lower rating of the same goal was recorded in an earlier study conducted among Belgrade fourth-grade secondary school students -2.89 . Nevertheless, 22\% of these students put this goal among five most important goals out of 18 offered to them (Kuzmanović \& Petrović, 2007).

In general, attitudes of Serbian citizens towards Europe reflected the political relations between Serbia and Europe that were shaped by both

20 The author used the results of a series of surveys by the Strategic Marketing Research Institute, conducted on representative samples of citizens of Serbia (without Kosovo) in the period of 2001-2006.

21 Data from www.seio.gov.rs 
European and Serbian politicians. Many significant events (mediated by their media presentation in Serbia) were responsible for this relation that resembles a zigzag line. In the spring of 1999 NATO launched a military intervention against the FRY that lasted for 78 days: all NATO countries were more or less involved in it. The European Union warmly welcomed the democratic changes in Serbia in 2000 and gave substantial assistance and support to the new government. Also, the EU welcomed the Serbian aspirations to EU and secured the necessary programmatic, technical and financial aid for the necessary reforms. However, Serbia was faced with additional barriers, at the first place the demand for cooperation with the International Criminal Tribunal for the Former Yugoslavia and for the solution of ethnic tensions in Kosovo. After that, Kosovo declared its independence in February 2008, although Serbia still claims it as a part of its sovereign territory as an autonomous province. The European Union then decided to deploy the European Union Rule of Law Mission in Kosovo, and by now 22 out of $27 \mathrm{EU}$ countries recognized Kosovo as an independent state. In April 2008 the European Union signed the Stabilization and Association Agreement (SAA) with Serbia and the document was ratified in the Serbian Parliament in September 2008, but its implementation has been temporarily suspended. When the UN General Assembly voted on Serbia's demand to seek the opinion of the International Court of Justice on the legality of Kosovo's independence on October 8, 2008, most EU countries abstained and five out of twenty seven countries voted in favour. The following year, the European Commission decided to allow the citizens of Serbia entry to Schengen countries visa-free from January 1, 2010.

\section{Foggy path to Europe}

Serbia is a society still far from consensus on what really happened in the past, on why, how to evaluate the key actors, and in what direction to go now. There is a broad spectrum of competitive views seeking to establish and assert their own truths, while the place of Europe in these narratives is often opposed. Serbian society is polarized regarding the past, cooperation with ICTY, the increase of traditionalism and ethnic nationalism. There is a strong anti-European front composed of influential parts of the political, economic and cultural elite, whose interests and convictions are against association with the EU. Political struggles during the period of elections in spring 2008 resulted in the prevalence of the pro-European forces (coalition „For a European Serbia") and in the formation of the pro-EU government. Since then, the anti-European campaign has been much less conspicuous, and there have been many more attempts to make the European Union more attractive and to build some kind of European identity. Actually, the goal positively valued by almost two-thirds of citizens can hardly be outside the agenda of any political party with the ambition to win the elections. The parties' 
,jumping on the bandwagon" leads to a growing support to such goal. ${ }^{22}$ The process of clear determination for the EU should result in positive gains. The accession would probably really fulfil citizens' expectations, at least of those occurring at the top in surveys as answers to the question: „What does the EU represent to you?". The most frequent answers were: a path towards better future of youth (54\%), better opportunities for employment (45\%), possibility to freely travel throughout Europe (44\%). ${ }^{23}$

For internal and international problems the solution to which is now unknown (the status of Kosovo, for example) or burdensome relations with the neighbouring countries, the expected association with the EU should bring some solutions, or decrease the intensity of problems, or make citizens more patient whilst waiting for a better moment for their solution. Ethnic identities will be moderate and less prone to provoke open conflicts. The symbolic significance of a powerful European Union, integrated around civic values, can play an important role in this direction.

The survey data show a constant discrepancy among Serbia citizens between their acceptance of the association with the EU and their attitudes towards the realization of particular European standards (Baćević, 2001). "Moving along the European path" will demand for this discrepancy to be reduced and the European standards more and more accepted. These Eurocriteria, accepted as instrumental goals whose realization is necessary for the terminal goal, are values by themselves. They are about the standards of protection and promotion of human and minority rights and a raised level of organizational culture and work ethics.

Finally, the process of association is a process of increased involvement in the work of the European institutions and cooperation with the latter; it implies greater integration in many fields even before the formal membership in the EU.

However, although the pro-European political elite appeals to the majority of citizens clearly determined for the association with the EU and represents

22 Less than six months after the secession of the Serbian Progressive Party (SNS) from the Serbian Radical Party (SRS), well-known as strongly opposed to European integrations, the former vice-president of the SRS and the president of the SNS, Tomislav Nikolić, called for an early election, in order to be seen "how far have we come with the European Union? Who is guilty for not going farther? Why are we doing nothing on this path?" (http:// www.b92.net/info/emisije/utisak_nedelje.php?yyyy=2010\&mm=04\&nav_id=425103).

23 It is indicative that these results from the daily Politika (January 27, 2008), then in the hands of the Euro-sceptic government, were published under the heading „Serbs don't believe Europe“. The graph with the data that tell about citizens' positive expectations from Europe was followed by referring to "the arrogance of European establishment, humiliation of Serbian citizens and the spite aroused as self-defence, feeling of disempowerment, double standards of the international community towards Serbia and the clear violation of all existing norms in the world in one single case“, followed by the comment that "the feelings of this kind cannot be captured by statistics". 
their interests, this group is criticized for confusing messages and failing to clearly shape the European option. ${ }^{24}$ Indeed, many publicly stated and frequently repeated messages and slogans contain apparent inconsistencies, or words ("European", „nations" and ,identity" among them) whose meaning should be clarified. ${ }^{25}$ This confusion seems not to be accidental or undesirable, but often desired. Intentional instability of the political context demands from the political actors to speak about Europe in an ambiguous way that commits as little as possible.

Serbia will not be the first nor the only country where approaching the European Union will be a movement along the path that lies between antagonistic „euro-petal“ and „euro-fugal“ forces, between „Euro-phobias“ and "Euro-utopias" (Mitev, 1997), and where the extreme alternatives are presented more consistently and more detailed than their resultant. The proEuropean campaign is being conducted through evasive messages, unclear statements with unclear phrases. Nevertheless, being like this (and perhaps, in current conditions, precisely for being such), it has a chance to succeed.

\section{References}

Baćević, Lj. (1990). Nacionalna svest omladine [National consciousness of youth]. In S. Mihailović (Ed.), Deca krize: omladina Jugoslavije krajem osamdesetih [Children of crisis: Yugoslav youth at the end of eighties] (pp. 147-172). Beograd: Institut društvenih nauka.

Baćević, Lj. (2001). Srbi i Evropa [Serbs and Europe]. Beograd: Centar za antiratnu akciju.

Balibar, É. (2001). Nous, citoyens d'Europe? Les frontières, l'État, le peuple. Paris: La Découverte.

Bogosavljević, S. (2007). Evropa i Srbija u Evropi u svesti građana Srbije [Europe and Serbia in Europe in perception of Serbian citizens]. In Z. Lutovac (Ed.), Političke stranke u Srbiji i Evropska unija [Political parties in Serbia and European union]. (pp. 51-62). Beograd: Friedrich Ebert Stiftung.

Brubaker, R., \& Cooper, F. (2000). Beyond „identity“. Theory and Society,29, 1-47.

Coser, L. A. (1956). The Functions of social conflict. New York: Free Press.

Dvorniković, V. (1939). Karakterologija Jugoslavena [Characterology of Yugoslavs]. Beograd: Kosmos.

24 Cf. Annual report for Serbia 2007 of Helsinki Committee for Human Rights in Serbia (2008).

25 Let us mention only a few recent newspaper headlines that could have been less enigmatic: „European identity of Serbia is historically confirmed“, „European institutions confirmed European identity of Serbia“, „Serbia without her own identity doesn't have anything to look for in Europe“, „Europe needs a soul, Europe needs Serbia“, „Young Serbs around the world shape the contemporary identity of Serbia“, „Independent Kosovo - attack on the identity of Europe“. 
Đorđević, M. (Ed.) (2003). Srpska konzervativna misao [Serbian conservative thought]. Beograd: Helsinški odbor za ljudska prava.

Eriksen, T. H. (2001). Ethnic identity, national identity, and intergroup conflict: the significance of personal experiences. In R. D. Ashmore, L. Jussim, and D. Wilder (Eds.), Social identity, intergroup conflict, and conflict reduction (pp. 42-68). Oxford: Oxford University Press.

Franceško, M., Kodžopeljić, J., i Mihić, V. (2005). European identity in Serbia and Montenegro. Psihologija, 38, 149-166.

Group of authors (2008). Serbia 2007. Self-isolation: The reality and the goal. Beograd: Helsinki Committee for Human Rights in Serbia.

Gvozden, V. (2007). Evropska unija i/ili evropski identitet [European Union and/or European identity]. Habitus, 14, 37-48.

Gvozden, V. (2008). Some remarks on the relationship between European identity and the European union. In K. Hanshew (Ed.), EU=Europe? Euroskepticism and European Identity (pp. 9-16). Forost Arbeitspapier Nr. 45. Munchen: Forost.

Hewstone, M. (1996). Contact and categorization: Social psychological interventions to change intergroup relations. In C. N. Macrae, C. Stangor, and M. Hewstone (Eds.), Stereotypes and stereotyping (pp. 323-368). New York: Guilford.

Imami, P. (2000). Srbi i Albanci kroz vekove [Serbs and Albanians through centuries]. Beograd: Samizdat FreeB92.

Jacobs, D., \& Maier, R. (1998). European identity: construct, fact and fiction. In M. Gastelaars \& A. de Ruijter (Eds.), A United Europe: The quest for a multifaceted identity (pp. 13-34). Maastricht: Shaker.

Janičić, B., Mihić, V. i Šakotić-Kurbalija, J. (2005). Odnos između evropskog i nacionalnog identiteta i rigidnosti kao crte ličnosti [Relation between European and national identity and rigidity as a personality trait]. Psihologija, 38, 461-473.

Jansen, S. (2005). Antinacionalizam: etnografija otpora u Zagrebu i Beogradu. [Antinationalism: an ethnography of resistance in Zagreb and Belgrade]. Beograd: XX vek.

Jović, D. (2009). Yugoslavia: a state that withered away. West Lafayette, In.: Purdue University Press.

Jović, D. (2001). Razlozi za raspad socijalističke Jugoslavije: kritička analiza postojećih interpretacija. Reč, 62/8, 91-157.

Kardelj, E. (1996). O društvenim i političkim osnovama FNRJ. In E. Kardelj, Problemi naše socijalističke izgradnje, knjiga II [Problems in our building of socialism, Vol 2]. (pp. 266-267). Beograd: Kultura.

Kostovicova, D. (2004). Post-socialist identity, territoriality and European integration: Serbia's return to Europe after Milosevic. GeoJournal, 61, 23-30.

Kuzmanović, B. \& Petrović, N. (2007). Struktura preferencija ličnih i društvenih ciljeva srednjoškolaca [Preference structure of personal and social goals of the highschoolers]. Psihologija, 40, 567-585.

Kuzmanović, B., \& Petrović, N. (2009). Preferencije ličnih i društvenih ciljeva srednjoškolaca [Preferences of personal and social goals in the high school pupils in Serbia]. Sociološki pregled, 43, 503-523.

Lendvai, P. (1991). Yugoslavia without Yugoslavs: The roots of the crisis. International Affairs, 67, 251-261. 
Marković, P. J. (2001). Odnos partije i Tita prema jugoslovenskom i nacionalnom identitetu [Relation of the party and Tito towards Yugoslav and national identity]. In L. Sekelj (Ed.), Identitet: Srbi i/ili Jugosloveni [Identity: Serbs and/or Yugoslavs] (pp. 13-62). Beograd: Institut za evropske studije.

Matvejević, P. (1983). Jugoslovenstvo danas [Yugoslavism today]. Beograd: BIGZ.

Milošević-Đorđević, J. (2003). Jedan pokušaj klasifikacije teorijskih razmatranja nacionalnog identiteta [An attempt of classification of theoretical approaches to national identity]. Psihologija, 36, 125-140.

Mitev, P. (1997). Euro-orientations, Euro-attitudes, Euro-utopias. In B. Jakšić (Ed.), Frontiers - The Challenge on Interculturality (pp. 179-188). Beograd: Forum za etničke odnose.

Putinja, F. i Stref-Fenar, Ž. (1995/1997). Teorije o etnicitetu [Theories of ethnicity]. Beograd: Biblioteka XX vek.

Robyn, R. (Ed.) (2005). The changing face of European Identity. London: Routledge.

Rot, N., \& Havelka, N. (1973). Nacionalna vezanost i vrednosti kod srednjoškolske omladine [National attachment and values of secondary-school youth]. Beograd: Institut za psihologiju, Institut drustvenih nauka.

Smith, A. D. (1992). National identity and the idea of European Unity. International Affairs, 68, 55-76.

Stojković, B. (1993). Evropski kulturni identitet [European cultural identity]. Niš: Prosveta.

Tajfel, H. (1978). Interindividual behaviour and intergroup behaviour. In H. Tajfel (Ed.), Differentiation between social groups (pp. 27-59). London: Academic Press.

Turner, J. C., Hogg, M., Oakes, P., Reicher, S., and Wetherell, M. (1987). Rediscovering the social group: A self-categorization theory. Oxford, U.K.: Basil Blackwell.

Vasović, M. (1990). Percepcija društvenih sukoba [Perception of social conflicts]. In S. Mihailović (Ed.), Deca krize: omladina Jugoslavije krajem osamdesetih [Children of crisis: Yugoslav youth at the end of eighties] (pp. 58-76). Beograd: Institut društvenih nauka.

DATUM PRIHVATANJA RADA 15.5.2010.

\section{Izgradnja evropskog identiteta: od dima iz dimnjaka}

\section{Dragan Popadić}

Filozofski fakultet Univerziteta u Beogradu

Prva Jugoslavija i njene naslednice nastajale su u periodima žestokih etničkih sukoba i bile su relativno kratkotrajne državne tvorevine, što je doprinelo visokoj izraženosti etničkih identiteta i etnonacionalizma kao i endemskoj slabosti građanskog identiteta njihovih stanovnika. U ovom tekstu opisana su tri pokušaja učinjena u ovim državama da se izgradi nacionalni identitet koji bi služio kao protivteža etničkom identitetu i smanjio rizik etničkih konflikata: promovisanje jugoslovenstva u SFRJ, razvijanje građanskih identiteta u državama-naslednicama, i promovisanje evropskog identiteta u Srbiji. Jedna od prepreka ka takvom cilju do- 
lazi i iz lingvističke konfuzije koja je već dugo vremena prisutna u svakodnevnom, političkom i naučnom diskursu. Značenje jugoslovenstva variralo je od vezanosti za državu do supra-etničkog identiteta sedme nacije. U srpskom jeziku ne postoji reč koja bi označila nacionalni a ne etnički identitet njenih građana. Izraz „evropski identitet“ se koristi namerno nejasno, (kao geografska pripadnost, prihvatanje sistema vrednosti, članstvo u političkoj zajednici itd.) što povećava konfuziju u javnom govoru. Trenutno, velike nade se polažu na razvijanje pozitivnih stavova prema evropskim integracijama i razvoju tzv. evropskog identiteta. Ono što nedostaje da bi taj proces bio efikasniji je udaljavanje od primordijalističkih shvatanja identiteta, relativno razvijen i stabilan nacionalni identitet, i konsenzus među političkom elitom o neophodnosti takvog puta. U sadašnim uslovima, proevropska kampanja se sprovodi putem nejasnih poruka ali, mada je takva (ili možda baš zato što je takva) ima veće šanse na uspeh od prethodna dva pokušaja čije perspektive su izgledale svetilije.

Ključne reči: etnički identitet, građanski identitet, evropski identitet, jugoslovenstvo, evropske integracije 